\title{
DIGITAL LITERACY IN EFL TEACHING
}

\author{
Nuriyatul Hamidah \\ UIN Sayyid Ali Rahmatullah Tulungagung \\ nuriyahamida@iain-tulungagung.ac.id
}

\begin{abstract}
Many questions have aroused in terms of media and technology used and its implication for language teaching and learning. The focus is on how students can be critically aware of media, especially digital media, for their learning. Thus, the use of media in education impacts educational creativity development, such as digital technology applications. In terms of learning, digital literacy is the competency in understanding and using digital technologies effectively for learning. Research has already explored the need for digital literacy in the classroom. This recent paper tries to figure out how digital literacy is implemented in the teaching of ESP students. Furthermore, the method used to describe the idea of this paper is a conceptual paper in which the writer tries to figure out how digital learning is implemented for learning. The writer used literature review from some journal articles and books written by the experts to gather the data. In conclusion, applying digital literacy must be well prepared on the way how it is used. It must relate to their competence, learning objectives, and language skills being taught. Indeed, once the students are familiar with the technology being used, they significantly improve their skills.

Keywords: Digital Literacy, EFL Learning, Language Skills
\end{abstract}




\section{INTRODUCTION}

Nowadays, with the improvement of technology, teachers are supposed to integrate technology into the classroom. In the 21st century, technology has become significant changes in many homes around the world. Its influence has invaded all facets of life, including English language teaching. This classroom engages students to be involved in the teaching and learning process using media served by technologies. Indeed, it is also believed that the use of technology in the language classroom can be integrated for EFL teaching and learning.

The integration of technology and language learning can help the teaching and learning process, the teachers can design their teaching appropriately with the use of technology. On the other hand, the students also seem easy to have an opportunity to increase their learning by using the technology. At this point, they are required to be capable of understanding the device. Thus, the more literacy skill on digital they have, the better they can utilize the technology for their learning. However, some students can use it while others are not able to. Then, the question will be focused on how they can operate it. In line with these descriptions, in an academic context especially in English language teaching and learning, digital literacy is also considered to be one of the important things to support students learning. As Harris (2015) proposed that digital literacy involves the way how they participate in community life, and gaining additional education and training. In summary, it is possible to include digital literacy as an important skill in the classroom to increase students learning process.

Recently, some research agrees on increasing student digital literacy as ease to help learners understanding the media or technology for their learning. Benson \& Chik, (2010) states that technological change influenced 
how learning and literacy in the 21st century are associated. Along with this reason, Schmar-Dobler (2003) stated that educators need to adapt and integrate the curricula into a new digital context. It is also supported by Kress (2003) and Luzón (2002) who suggested that the teachers are required to use any accessible digital tools to ensure that education is appropriate to the requirements of today's society.

To be more specific, the technology gives some effect on literacy abilities both in and outside of the school setting. In this context, when talking about digital literacy, the use of technology is also included. As supported by Grimshaw, Dungworth, and McKnight (2007) on their studies revealed that the use of technology may affect students' skill in reading comprehension. Emphasizing digital literacy for students reading skills may give an impact on their ability in comprehending the text. It is also supported by the finding of Ertem (2010) figured out that there was a significant improvement in reading compression when the students are engaged in digital texts which incorporated animations.

Nevertheless, some considerations should be taken to foster students' digital literacy. The teachers are supposed to make an assessment to identify their own and their students' digital literacy skills and goals. Besides, the instructions and teaching media must be of interest to the student. Because some students are not quite interested in technology. In this context, digital literacy is more than just being able to use technology; it similarly includes the ability to find information. As it is argued by Hague \& Payton (2010), digital literacy can be defined as the ability to access, share, create, collaborate and communicate effectively by applying digital media.

Further, this paper aims to give some review on how digital literacy is applied in language learning. Thus, the result shows the explanation on the 
way how it is applied as well as described the element that the teacher needs to know when maximizing digital literacy for their teaching. Moreover, the writer also provides a review on digital literacy which is applied in language skills that are speaking, listening, reading, and writing skills.

\section{METHOD}

This present study uses a qualitative research method. Qualitative research focuses on understanding people's beliefs, experiences, attitudes, and behaviours (Creswell, 2007). While this study is a theoretical research paper. It is carried out in the interpretive paradigm. Therefore, the data collection is done using documentation techniques. In this paper, the writers explain more about what digital literacy is that can be meaningful for English learning. It explains how digital literacy affects students' learning as well as the instruction designed related to digital literacy. Then, reviewing some literature from the field to identify the role of digital literacy to support students' learning. Thus, this study is based on a conceptual research, it focuses on some reviews about digital literacy that is viewed effectively to maintain students' learning.

\section{FINDINGS AND DISCUSSION \\ Digital Literacy}

Nowadays, the appearance of the internet and the development of technology have provoked changes in literacy and created a new form of literacy (Schmar-Dobler, 2003). The term digital literacy has been considered as a source in the learning process. In this context, in the education setting the teachers are required to be the facilitator and motivators who help students to prepare in the next phase of the digital environment by 
employing digital literacy in the classroom like utilizing information and communication technology (ICT) in EFL teaching and learning process. Regarding those roles, both as facilitators and motivators in the classroom, the success of the use of digital literacy in the classroom is related to teachers' decisions about the materials. Thus, the students are supposed to learn how to use technological resources to support their learning (Thorne, Black \& Sykes, 2009; Dooly, 2014).

One of the uses of ICT is using the internet in the classroom. Gathering information from the internet sometimes requires a specific type of literacy such as using hyperlinks or application of critical thinking. As a consequence, students may be strained due to unsuccessful search of information. Hence, as educators, we need to foster new literacies in the classroom by providing appropriate ICT in the classroom.

In relation to the discussion above, to face this competency in using digital media especially in the educational area. The writer suggests strengthening digital literacy especially for students who are learning how to comprehend and be successful in language learning. The term Digital Literacy can be understood as two dimensions, literacy and digital. Digital literacy is a skill that relates to the capability of using a variety of digital technologies for different purposes. Eisenberg (2008) defines digital literacy as a set of abilities and knowledge that allows us to find, organize, understand, evaluate, and use the information we need through digital technologies. In the classroom, digital literacy takes on many forms, for example, it includes when the teachers and students use social network applications to create effective learning, creating online content which can be utilized whether it is inside or outside the classroom. In short, the term digital literacy in the classroom can be defined as the way how technology is 
linked into teacher-student relationships, broadening the way teachers present lessons, constructing assessments, and communicating with the students. Moreover, it also includes social engagement, skills, and competencies that promote students' critical thinking, and the ability to judge information for trustworthiness and relevance.

\section{Digital Literacy in English Language Instruction}

Once the teachers are going to applied digital literacy in English class, they need to consider some points. What the things need to be concerned about are the teachers need to design instructional solutions to foster new literacy in the classroom, it can be from the Internet. First of all, the teacher should know what the students need, they must be provided some opportunities to experience the technology for themselves. The teacher should plan for the time it takes to do this.

Moreover, they also need to know whether the instruction is efficient for students' literacy or not. Thus, the teachers need to give some instructions to the student appropriately. Here, we proposed that the Internet, for instance, could be the main medium in which both the teachers and students can share everything, especially for their learning. Indeed, the new technologies in combination with the new literacies might offer valuable support for students' learning such as in students' reading development. This idea is also supported by Ciampa (2012) who revealed that using e-book in English class can help students to be more motivated. The result shows that the students are highly motivated to read and write when using e-books.

Furthermore, the most important one when we are going to implement digital literacy for English language instruction is we need to 
know students' proficiency level both in English and in technology use. After their proficiency level is identified, then defining the learning objective of the lesson which is related to the digital literacy skills must be the main goal since the aim is to develop their proficiency both in English and in technology use. Objectives here meant as what the instructor believes students will be able to do by the end of class. Hence, classroom activities should reflect the objectives. A standard objective refers to what students will be able to do at the end of the course. To create meaningful objectives, the instructor needs to evaluate the tools that students will need to accomplish these objectives.

Besides, the lecturer must know what kind of strategies will be used in the classroom to help the student reaching the lesson objective. Thus, consider the technology that students will use in their daily practices. The importance of digital literacy cannot be separated from the daily classroom. It is important to select some media and material which can be taken from videos or websites to teach both language content and skills. Thus, the teacher or lecturer needs to consider the use of technology as well as the lesson being taught such as the material or the topic as a part of learning content. Another concern is what skill is being trained. Thus, the content and also language skill can be taken at the same level.

Then, the design for the classroom activities can be focused on student-centered as the primly practiced activities in the classroom. This approach aims to engage students actively involved in their learning which is meaningful to their lives (Peyton, Moore, \& Young, 2010). Hence, this technique would be more beneficial for students' achievement and their acquisition as well. Besides, creating digital literacy also cannot be separated from the material which is authentically constructed for students' learning. 
Hence, the material design should cover some criteria like providing thematic units, constructing problem-based learning, or project-based learning. Those designs provide content into which authentic digital tasks can be integrated and combined. Since it is language learning then the unit would include some lessons such as vocabulary, grammar, and so on.

As English Language Learning develops basic digital literacy skills, many opportunities will arise to extend English language acquisition outside the class. Since the learners are capable of maintaining digital literacy, they may have the capability to create and communicate with others through online platforms. This situation may provide unlimited English language acquisition activities. Related to this description, digital literacy skills can be included into four language skills; speaking, listening, reading, and writing. As mentioned in the U.S. Department of Education, any project, topic, theme, or problem-based approach can be extended including language skills that are speaking, listening, reading, and writing. The next is discussing those four skills briefly.

In the speaking classroom, the use of digital tools along with the lesson objective for speaking class can be implemented when the students are required to create a recorded audio file that is put online hence the others can listen and download that audio. This activity can make students more enthusiastic in which creating multimedia products can be highly motivating to the students. Some activities that can be implemented for listening class are the students might be given an individual assignment to listen to podcasts, YouTube videos, and another. Thus, it is required that teachers should differentiate instruction and better meet the diverse needs, interests, and abilities of the students. 
Other, reading skills and instructional language skills using a text or online texts can be meaningful. Using images, hyperlinks to word meanings, illustrative videos, and recordings of word pronunciations can support the learning process. They also learn vocabulary as they interact with these various aspects of word meaning. In addition, as reading strategy is important for print reading, this thing should also be considered in digital environments.

The last, writing skill is also considered to be authentic in which the classroom will be essential since the students are required to write any information for the readers. Such writing projects may permit students to learn vocabulary, grammar, and digital literacy. Further, writing-based technologies, especially those involving the Internet such as blogs, digital stories, and wikis provide many opportunities for them to be an author. Those digital tools can be used to communicate in and outside the classroom. As it is supported by Thorne (2009) writing for audiences outside the classroom can construct and maintain identities as well as build community. Thus, when the writers have the same idea, they might build up a new community that is interested in the same field.

From the previous discussion above, here is an example of a lesson plan which is for the ESL beginning level. In this lesson plan, the students are required to create a paragraph using simple present and the "be" verb as the objective of language learning. At the end of the class, they will be divided into small groups to discuss the paragraph that they created. They may share their commands or suggestion. The following is a brief description of the lesson plan. 


\section{BL'PALL (ENGLISH IANGUAGE 'TEACHING, APPLIII) LINGUIS'IICS ANI LI'TRRA'TURE)}

Vol. 2 No. 2, 2021

Available online at https:/ /jurnal.iainponorogo.ac.id/index.php/eltall

Lewel: ESL beginning

Unit focus: Personal Information

Class length: 2 hours (45 minutes in the classroom and 1 hour and 15 minutes In the lab)

Language-learning objective: Create a paragraph about your family, using the simple present tense and the be verb.

Digital literacy objective: Use word processing to publish a paragraph.

WARM-UP

Before golng to the lab, ask several students to read thelr paragraphs about personal information from previous lessons.

\section{INTRODUCTION}

While stull in class, review the lab rules and the previous handout with steps students followed for the previous visit, when they transferred their personal information paragraphs to digital documents. State the objectuve and imite students to go to the lab.

\section{PRESENTATION/PRACTICE}

This time, ask each student to sit at his or her own computer, Instead of forming groups of three, as they did before. Make sure to assign students who struggle with technology to sit near those who are more proficlent. Pass out a copy of the rubnc to each student. The rubric has two sections, one for writing and one for digital Iiteracy skills. Review all the categorles and demonstrate again how to open and close documents, and how to center and use the shift key for uppercase letters. Give students a handout describing the steps for this visit to the lab. Review it with them.

\section{EVALUATION}

Have students open their documents, which they saved in a special folder on the desktop during the previous lab visit. Identufy students who could not do this task on their own and ask student mentors to help them.

\section{APPUCATION}

Ask students to type their paragraphs and save their work to the same folder they saved it to dunng the last lab visit. Ask students to pint their paragraphs. Have them share their paragraphs with a partner while reviewing the rubric. Ask students to read their paragraphs to the class.

Adapted from LINCS: Integrating Digital Literacy Into English Language Instruction 


\section{CONCLUSION AND SUGGESTION}

Nowadays, the use of technology is also included in English Language Lerner. The use of technology for language learning presents some opportunities for students' language acquisition. Thus, they need to be accustomed to the use of technology in the classroom. Thus, digital literacy skill is needed. This skill refers to what people do with technology.

To develop digital literacies within educational programs, it is needed to determine the tools being used which can be integrated with the learning practices directed towards the learning of course content and achieving learning objectives. It can be inferred that the use of digital devices has to be in line with the objectives and the goal of learning. Indeed, learning environments also should be designed with the complexity of learning processes.

Some factors need to be considered when trying to improve student's literacy skills. First of all, the teacher needs to be aware of students' background knowledge. Of course, in one class, there should be different abilities, knowledge, and motivation. In this case, once the teacher enhances students' digital literacy, s/ he needs to consider those factors. As mentioned in the U.S. Department of Education, EFL learners come from different backgrounds. They can differ from both learning experiences, language skills, and levels of experience with print literacy and technology. It can affect their ability to acquire digital literacy skills.

This study proposed the conceptual theory of digital literacy in lagage teaching. Thus for the upcoming researcher who are interested in conducting a research, future studies should cover the practice of applying digital literacy in language classroom which cover the instruction and the content of the lesson and the learning outcome. 


\section{REFERENCES}

Benson, P. \& Chik, A. (2010). New literacies and autonomy in foreign language learning. In M-J. Luzón, M.N. Ruiz-Madrid \& M.L. Villanueva (Eds.) Digital genres, new literacies and autonomy in language learning (pp. 63-80). Newcastle-upon-Tyne: Cambridge Scholars Publishing.

Ciampa, K. (2012). Reading in the Digital Age: Using Electronic Books as a Teaching Tool for Beginning Readers. Canadian Journal of Learning and Technology, 38(2).

Creswell, J. W. (2007). Qualitative inquiry and research design: Choosing among five approaches (2nd ed.). Sage Publications, Inc.

Ertem, I. (2010). The Effect of Electronic Storybooks on Struggling FourthGraders' Reading Comprehension. Turkish Online Journal of Educational Technology - TOJET, 9(4), 140-155.

Eisenberg, M. B. (2008). Information literacy: Essential skills for the information age. Journal of Library and Information Technology, 28(2), 39-47.

Grimshaw, S., Dungworth, N., \& McKnight, C. (2007). Electronic Books: Children's Reading and Comprehension. British Journal of Educational Technology, 38(4), 583-599.

Hague, C. \& Payton, S. (2010). Digital Literacy in Practice (Case Studies of Primary and Secondary Classroom). UK: Futurelab Retrieved from www.futurelab.org.uk

Harris, K. (2015). Integrating digital literacy into English language instruction (Issue Brief). Washington, DC: U.S. Department of Education, Office of 
Vol. 2 No. 2, 2021

Available online at

https:/ /jurnal.iainponorogo.ac.id/index.php/eltall

Career, Technical and Adult Education. Retrieved from https://lincs.ed.gov/programs/eslpro

Kress, G. R. (2003). Literacy in the new media age. London: Routledge Falmer.

Luzón, M. J. (2002). The spoken features of academic and professional electronic discourse. Oral Skills, Resources, and Proposals for the Classroom: 147-160.

Schmar-Dobler, E. (2003). Reading on the Internet: The link between literacy and technology. Journal of Adolescent \& Adult Literacy, 47(1): 80-85.

Thorne, S.L., Black, R., \& Sykes, J. (2009). Second language use, socialization, and learning in Internet interest communities and online gaming. Modern Language Journal, 93: 802-821.

Thorne, S. L. (2009). Mediating technologies and second language learning. In J. Coiro, M. Knobel, C. Lankshear, \& D. J. Leu (Eds.), Handbook of research on new literacies (pp. 415-447). New York, NY: Routledge. 